\title{
Bolkar Dağlarındaki Eski İşletmeler Vadisinde Yeni Yaş Bulguları ve İlk Maden Ruhsatı: Yazılıtaş (Niğde)
}

\author{
New Age Findings in Ancient Mining Valley \\ in Bolkar Mountains and First Mining Licence: Yazılıtaş, Niğde
}

\author{
Ahmet KARTALKANAT \\ MTA Genel Müdürlügüu, Maden Etüt ve Arama Dairesi, Ankara
}

(kartalkanat@hotmail.com)

\section{ÖZ}

Niğde (Ulukışla) ve Adana (Pozantı) il sınırları içerisinde bulunan eski maden işletmesi ve cüruf sahalarında eski madenciliğe yönelik çalışmalar yapılmıştır. Bu yörelerdeki eski maden işletmelerinde ve bunların cüruflarından kimyasal analiz ve $C^{14}$ yaş tayini için numuneler alınmıştır. Madenköy'deki cürufların kimyasal analizlerinde $0,8 \mathrm{~g} / \mathrm{t}$ Au ve 142,1 g/t Ag; Alihoca-Karagöl Mevkii'ndeki cüruflarda 1,3 g/t Au ve 34,7 g/t Ag; Gümüşköy'deki cüruflarda 0,9 g/t Au ve 67,9 g/t Ag; Madenköy-Karagümüş Mevkiindeki cüruflarda ise 1,3 g/t Au ve 92,8 g/t Ag saptanmıştır.

Madenköyü, Yeşelli-Büyük Toyislam eski maden işletmelerinde küçük ve büyük su tekneleri, ağaç tahkimatı, ahşap kürek, eski çıra bulunmuştur. Bu buluntularda $\mathrm{C}^{14}$ yöntemi ile yapılan yaşlandırmalarda;

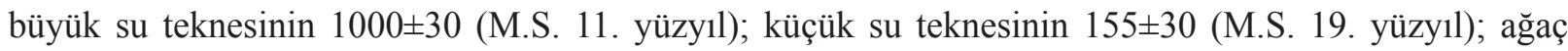
tahkimatın 105 \pm 30 (M.S. 19. yüzyıl) saptanmıştır. Maden köyü-Büyük Toyislam’da bulunan iki ahşap

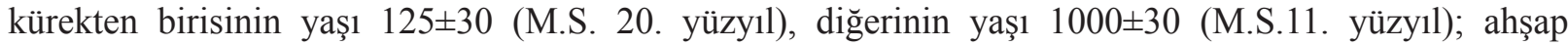
tahkimatın yaşı $600 \pm 30$, eski çıranın yaşı ise $385 \pm 30$ y1l olarak belirlenmiştir. Horozköy-Gavurun Damı Mevkii'nde bulunan eski maden işletmesinden alınan eski çıranın yaşı $270 \pm 25$ (M.S. 18. yüzyıl); eski

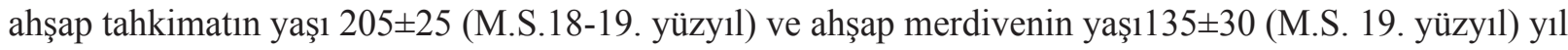
olarak belirlenmiştir.

Ayrıca Karagümüş Mevkii ile Madenköy'de bulunan cüruf yığınlarının bünyelerinde bulunan odun kömürlerinin $C^{14}$ yaşı sırasıyla $835 \pm 30$ (M.S. 12. yüzyıl) ve $860 \pm 30$ (M.S. 12. yüzyıl) yıl olarak saptanmıştır. Yaş bulgularına göre, eski maden işletmelerindeki madencilik faaliyetlerinin Bizans Dönemi’nden, Cumhuriyet Dönemi’ne kadar aralıklarla da olsa yürütüldüğünü göstermektedir.

Alihoca köyünün doğusunda bulunan ve M.Ö. 800 yıllarında bölgede yaşamış olan Neo-Hitit Dönemi’ne ait olduğu saptanan yazıtta, Bolkar Dağları "Muti Dağı” olarak isimlendirilmektedir. Bu yazıtın tarihteki ilk maden ruhsatı olduğu kabul edildiğinde Bolkar Dağlarında bulunan bu eski işletmelerin M.Ö. 800 yıllarından bu yana, yani Neo-Hitit döneminden günümüze kadar işletildiğini ifade etmek mümkündür. 
Anahtar Kelimeler: $\mathrm{C}^{14}$, eski işletmeler ve cüruflar, ilk maden ruhsatı, madencilik aletleri, Muti (Bolkar) dağı, Yazılıtaş, yeni yaş bulguları

\begin{abstract}
Ancient mines and mining slag's around Ulukışla (Niğde) and Pozantı (Adana) region were investigated in terms of ancient mining point of view. Samples were collected for chemical and radiometric $\left({ }^{14} \mathrm{C}\right)$ analysis from ancient ores and slag's. According to the chemical analysis, Madenköy slags includes $0.8 \mathrm{~g} / \mathrm{t}$ Au and $142.1 \mathrm{~g} / \mathrm{t} \mathrm{Ag}$; Alihoca-Karagöl slag's includes $1.3 \mathrm{~g} / \mathrm{t}$ Au and $34.7 \mathrm{~g} / \mathrm{t} \mathrm{Ag}$; Gümüşköy slag's includes $0.9 \mathrm{~g} / \mathrm{t}$ $\mathrm{Au}$ and $67.9 \mathrm{~g} / \mathrm{t} \mathrm{Ag}$, and Madenköy-Karagümüşs slag's are includes $1.3 \mathrm{~g} / \mathrm{t} \mathrm{Au}$ and $92.8 \mathrm{~g} / \mathrm{t} \mathrm{Ag}$.

Different size vessels, wooden fortifications and shovels and firewood's were discovered around Madenköyü, Yeşelli-Büyük Toyislam ancient mines. ${ }^{14} \mathrm{C}$ analysis of big vessel gives $1000 \pm 30$ years (11th Century A.C.); small vessel gives $155 \pm 30$ (19th Century A.C.); wooden fortification gives $105 \pm 30$ (19th Century A.C.) radiometric ages. Two wooden shovel discovered around Maden köyü-Büyük Toyislam gives $125 \pm 30$ (20th Century A.C.) and 1000 30 (11th Century A.C.); wooden fortification gives $600 \pm 30$ (15th Century A.C.); firewood gives $385 \pm 30$ (17th Century A.C.) radiometric ages. Firewood of the ancient mine around Horozköy-Gavurun Damı region gives $270 \pm 25$ (18th Century A.C.); ancient wooden fortification gives $205 \pm 25$ (18th-19th Century A.C.) and wooden staircase gives $135 \pm 30$ (19th Century A.C.) radiometric ages.
\end{abstract}

Wooden charcoals were also analysed according to ${ }^{14} \mathrm{C}$ ages of slag mounds around Karagümüş and Madenköy; $835 \pm 30$ (12th Century A.C.) and 860 30 (12th Century A.C.) radiometric ages were observed respectively. According to these radiometric ages, mining works is active starting from Byzantian era to the Republic of Turkey with some interruptions in the region.

Bolkar Mountains is called as "Muti Mountains" in the tablet of Neo-Hatti period in 800 BC, located in eastern part of Alihoca Village. This tablet could be accepted as the "first mining licence" according to its content, thus, mining in the region is active, with some interruptions, since Neo-Hatti Period.

Keywords: Ancient mines and slag's, first mining licence, mining staff, Muti (bolkar) mountains, new ${ }^{14} \mathrm{c}$ radiometric ages, Yazılıtaş.

\section{GíRiș}

$\mathrm{Bu}$ çalışma MTA Genel Müdürlüğü tarafından yürütülen bir proje kapsamında gerçekleşmiştir. Niğde ili Ulukışla ilçesi Çiftehan'a bağlı Alihoca, Maden ve Gümüşköy ile Adana ili Pozantı ilçesine bağlı Horozköy'de bulunan 12 ayrı işletmede eski madenciliğe yönelik çalışmalar yürütülmüştür. $\mathrm{Bu}$ eski işletmelerde bulunan ve $\mathrm{C}^{14}$ yaş analizi yapilarak tarihlendirilen materyaller MTA
Tabiat Tarihi Müzesine kazandırılmıştır. Niğde ili Ulukışla ilçesi Çiftehan Beldesi Alihoca köyünün yaklaşık $3 \mathrm{~km}$ doğusunda bulunan 3-4 m yükseklikte bir kayada, 5 satırlık Hiyeroglif yazı ile yazılmış olan bir yazıt bulunmaktadır. $\mathrm{Bu}$ yazıtta, Bolkardağları "Muti Dağı" olarak isimlendirilmekte, "Efendim Warpalawas'a iyilik ettim, o da Muti Dă̆g'nı bana verdi ve bereketli olmasını diledi” denilmektedir. Bu yazıtın ilk maden ruhsatı olduğu kabul edilmektedir. 
Sahada bulunan 30'a yakın eski işletmenin girilebilen 8 'inde ve 3 ayrı cüruf sahası ile ilk maden ruhsatı olarak isimlendirilen Yazılıtaş’ta çalışmalar yürütülmüştür (Şekil 1). Bolkardağ-1 sahasında Sulucadere, Öküzgönü ve Gavurun Damı; Bolkardağ-2 sahasinda ise Yeşelli, Tenekeli, Sulu Mağara, Davalı ve KA-A (KH) Mağarası'nda eski madenciliğe yönelik çalışmalar yoğunlaştırılmıştır. Ayrıca Maden köyü cüruf sahası, Gümüşköy cüruf sahası ve Maden Köyü-Karagümüş mevkii cüruf sahasında rezerve ve madencilik tarihine yönelik çalışmalar gerçekleştirilmiştir.

$\mathrm{Bu}$ çalışmada Bolkardağı yöresindeki tarihsel dönemleri temsil eden eski işletmelere ait yeni yaş bulguları ile ilk maden ruhsatı olma özelliği gösteren Yazılıtaş'ın öneminin altı çizilmiştir.

\section{ESKI MADEN İŞLETMELERININ TARIHÇESİ}

Bolkardağları yöresinde bulunan eski işletmelerde yapılan çalışmalardan ve çevresinde bulunan yazıtlardan (Yazılıtaş) hareketle, bu bölgedeki madenlerin M.Ö. 8.yüzyıldan beri işletildiği bilinmektedir. Birçok yazılı kaynak eski işletmelerin önce Hititler, daha sonra Bizanslılar tarafından işletildiğini belirtmektedir (Hannebert, 1888). Bu bölgede antik madencilik izlerine ve antik dönemlerden kaldığı sanılan cüruf yığınlarına, Avrupalı jeologlar 19.yüzyıldan itibaren yazdıkları raporlarında yer vermiş ve kayıt altına almışlardır (Beral, 1865; Hannebert, 1888). Hannebert'in (1888) raporuna göre işleyen maden ocağı sayısı yirmidörttür. Yeşelli işletmesinin giriş kısmında kalker üzerine yapılan haç işareti ve 1880 yılı yazısı, o yıl ocakta hayatını kaybeden Rum madencilerin isimleri ile tarihleri yazılarak madencilerin anısı için yapılmıştır. Her ocak, işletmeyi yapan kişilerin ismiyle anılmış olup, Cumhuriyet Dönemi'nde ocak sayısı otuzun üzerindedir (Cokino, 1927). Elde edilen gümüşün İstanbul'a nakliyesi devlete ait olmuştur (Yener, 1938).

Osmanlılar Devleti Dönemi’nde "Bulgar Madeni" ismi ile anılmakta olan bu saha yazılı kaynaklara göre 1825 yllında tekrar işletmeye açılmıştır (Beral, 1865). İşletme, Gümüşhane'den getirilen ve Madenköy'e yerleştirilen Rum kökenli madenciler tarafından yapılmıştır. Devlet, madencilerin işletme yapabilmeleri için arazi, para, alet, barut, tulum ve buğday yardımında bulunmuş, ayrıca cevherin taşınma masraflarını da üstlenmiştir. O tarihte üretimde olan galeri sayısı onüç olup, 1863 yılında beş, 1864 yılında ise on galeri açılmıştır. İşletmede tamamen ilkel şartlarda cevherin dalımı takip edilmek suretiyle üretim yapılmıştır (Beral, 1865).

1927 y1linda 120.000 ton cevherin işletildiği ve 57.000 ton cüruf yığınının bulunduğu belirtilmektedir (Hill ve Stewart, 1927). Ayrıca, Madenköy'de 96.000 ton cüruf, onüç firın ve dört küpelasyon işletmesi bulunduğundan söz edilmektedir (Tylecote, 1980). Ancak günümüzde burada 30-40 bin ton cüruf kalmıştır. Balkan Savaşı'nın çıkması üzerine, 1912 yılında madenin işletmesi devlet tarafindan durdurulmuştur (Ralli,1925). Daha sonra, 1925 y1lında, maden işletmesi, İş Bankası ve B.Edip Servet'in uhdesine geçmiştir. 1930 ve 1950'li yıllar arasında tekrar Etibank tarafindan işletmeye alınan saha günümüzde özel sektörce işletilmektedir.

\section{SAHANIN GENEL JEOLOJISI}

İnceleme alanı, Orta Toroslar'ın Bolkardağları yöresinde Bolkardağ Birliği içerisinde bulunmaktadır (Şişman ve diğerleri, 1981). Sahada sedimanter kayalardan Permiyen'den başlayan ve 
Triyas, Kretase, Tersiyer'e kadar uzanan bir çökel seri bulunmaktadır (Şekil 2). Kuvaterner yaşıı alüvyonlar bu birimleri örtmektedir. Permiyen ve Triyas yaşlı birimler üzerinde metamorfizma etkisi görülmektedir. Yörede Paleosen-Alt Eosen yaşlı volkano-sedimanter kayaçlar ile granit, granodiyorit, siyenit ve bunların damar kayaları bulunmaktadır (Şişman ve diğ., 1981).

Bölgedeki kurşun-çinko, altın, gümüş, bakır ve az da olsa demir cevherleşmeleri, PermoTriyas yaşlı mermerler ile Alt Paleosen-Alt Eosen yaşlı volkanitler içinde yer alır (Şişman ve diğerleri, 1981). Bolkardağ ve yöresinde ekonomik açıdan oldukça önemli olan ve çok eskiden beri bilinen ve işletilen altın ve gümüş içeriği yüksek kurşun-çinko yatakları bulunmaktadır. $\mathrm{Bu}$ cevherleşmeler genellikle sülfidli minerallerden (pirit, pirotin, markasit, galenit, sfalerit, kalkopirit gibi) oluşmaktadır ve hidrotermal kökenlidir (Şişman ve diğerleri, 1981). Mineralizasyonu meydana getiren cevherli eriyikler köken olarak Horoz Granit-Granodiyoriti ile ilişkilidir (Şişman ve diğerleri, 1981). Bu cevherli eriyikler Bolkardağ mermerlerinin çatlak ve boşluklarında birikerek esas cevherleşmeyi oluşturmuşlardır. $\mathrm{Bu}$ cevherleşmeler daha sonra yeraltı suları ile taşınarak ikincil cevherleşme noktalarında birikmişlerdir (Şişman ve diğerleri, 1981).Çalışma sahasında çökel kayalar çoğunlukla kıvrımlı ve faylıdır. Kıvrım eksenleri yaklaşık doğu-batı, faylar yaşlıdan gence doğru doğu-batı, kuzeydoğugüneybat1,kuzey-güney doğrultusundadır.

\section{MATERYAL VE YÖNTEM}

Niğde ili Ulukışla ilçesi Çiftehan'a bağlı Alihoca, Maden ve Gümüşköy ile Adana ili Pozantı ilçesi Horozköyü'nde bulunan 17 ayrı eski maden işletmesi ve cüruf sahasından, 8'i eski maden işletmesi, 3'ü cüruf sahası olmak üzere toplam 11 alanda eski madenciliğe yönelik çalışmalar yapılmıştır. Maden, Alihoca, Horoz ve Gümüşköy’ün yer aldığı bu eski maden işletmelerinde ve bunların cüruflarından 7 adet kimyasal, 12 adet $\mathrm{C}^{14}$ yaş analizi için numuneler alınmıştır. Ana oksitler ile bazı iz element $(\mathrm{Pb}$, $\mathrm{Zn}, \mathrm{Cu}, \mathrm{As}, \mathrm{Sb}, \mathrm{Cr}, \mathrm{Sn}, \mathrm{Au}$ ve Ag) analizleri MTA Genel Müdürlügü laboratuvarlarında Thermo XRF cihazı ile UQ programında yapılmış olup örnekler öncesinde $105{ }^{\circ} \mathrm{C}$ 'de kurutulmuştur. $\mathrm{SO}_{3}, \mathrm{PbO}$, $\mathrm{ZnO}$ ve $\mathrm{Fe}_{2} \mathrm{O}_{3}$ analizlerinden bazıları yaş analiz ile karşılaştırılıp doğrulanmıştır. $\mathrm{C}^{14}$ radyometrik yaş tayinleri ise ETH Zurich, Laboratory of Ion Beam Physics Radiocarbon Dating Laboratuvarında yapılmıştır. Kalibre edilmiş ${ }^{14} \mathrm{C}$ yaşları için $\mathrm{OxCal}$ v3.10 cihazı kullanılmıştır. 12 örneğe ait $C^{14}$ yaşlandırma sonuçları Çizelge 1 de sunulmuştur. 
Çizelge 1. Eski işletmelere ait $\mathrm{C}^{14}$ yaşlandırma sonuçları.

Table 1. $\quad \mathrm{Cl}^{4}$ ages of the materials in ancient mines of Bolkardağ region.

\begin{tabular}{|c|c|c|c|c|c|c|c|}
\hline Örnek no & Laboratuar no & Örnek kodu & Lokalite & Materyal & $\begin{array}{l}\mathrm{C}^{14} \text { yaş } \\
(\mathrm{BP})\end{array}$ & Delta $C^{13}(\%)$ & Dönemi \\
\hline Kartal 1 & ETH-44810 & TR-11/02-06 & $\begin{array}{l}\text { Alihoca -Yeşelli } \\
\text { doğu }\end{array}$ & $\begin{array}{l}\text { Eski galeriden } \\
\text { ahşap }\end{array}$ & $105 \pm 30$ & $-23,5 \pm 1,1$ & $\begin{array}{l}\text { M.S. 19.yüzy1l } \\
\text { (Osmanlıların } \\
\text { son dönemi) }\end{array}$ \\
\hline Kartal 2 & ETH-44811 & TR-11/02-07 & $\begin{array}{l}\text { Alihoca-Yeşelli } \\
\text { doğu }\end{array}$ & Ahşap tekne & $1000 \pm 30$ & $-22,3 \pm 1,1$ & $\begin{array}{l}\text { M.S. 10-11. yüzyıl } \\
\text { (Bizans Dönemi) }\end{array}$ \\
\hline Kartal 3 & ETH-44812 & TR-11/02-08 & $\begin{array}{l}\text { Alihoca -Yeşelli } \\
\text { doğu }\end{array}$ & Ahşap tekne & $155 \pm 30$ & $-24,1 \pm 1,1$ & $\begin{array}{l}\text { M.S. 19.yüzy1l } \\
\text { Osmanlıların } \\
\text { Son dönemi (II. } \\
\text { Mahmut-II. } \\
\text { Abdülmecit) }\end{array}$ \\
\hline Kartal 4 & ETH-44813 & TR-11/04-03 & $\begin{array}{l}\text { Horoz Köyü- } \\
\text { Gavurun Damı }\end{array}$ & Çıra parçası & $270 \pm 25$ & $-20,9 \pm 1,1$ & $\begin{array}{l}\text { M. S. 18. yüzyıl } \\
\text { (Osmanlı Dönemi) }\end{array}$ \\
\hline Kartal 5 & ETH-44814 & TR-11/04-04 & $\begin{array}{l}\text { Horoz Köyü- } \\
\text { Gavurun Damı }\end{array}$ & Ahşap direk & $205 \pm 25$ & $-20,7 \pm 1,1$ & $\begin{array}{l}\text { M.S. 18-19.y.y. } \\
\text { (Osmanl1 Dönemi) }\end{array}$ \\
\hline Kartal 6 & ЕTH-44815 & TR-11/04-05 & $\begin{array}{l}\text { Horoz Köyü- } \\
\text { Gavurun Damı }\end{array}$ & $\begin{array}{l}\text { Ahşap } \\
\text { merdiven }\end{array}$ & $135 \pm 30$ & $-22,5 \pm 1,1$ & $\begin{array}{l}\text { M.S. 19.y.y } \\
\text { (Osmanl1 Dönemi) }\end{array}$ \\
\hline Kartal 7 & ETH-44816 & TR-11/0502a & $\begin{array}{l}\text { Alihoca- Büyük } \\
\text { Toyislam }\end{array}$ & Ahşap kürek & $1000 \pm 30$ & $-24,2 \pm 1,1$ & $\begin{array}{l}\text { M.S. 11.yüzy1l. } \\
\text { (Bizans dönemi) }\end{array}$ \\
\hline Kartal 8 & ETH-44817 & TR-11/0502b & $\begin{array}{l}\text { Alihoca- Büyük } \\
\text { Toyislam }\end{array}$ & Ahşap kürek & $125 \pm 30$ & $-23,0 \pm 1,1$ & $\begin{array}{l}\text { 19. yüzyılın } \\
\text { başlarında } \\
\text { (Osmanlı Dönemi) }\end{array}$ \\
\hline Kartal 9 & ETH-44818 & TR-11/05-05 & $\begin{array}{l}\text { Alihoca- Büyük } \\
\text { Toyislam }\end{array}$ & Cira parcasi & $385 \pm 30$ & $-22,8 \pm 1,1$ & $\begin{array}{l}\text { M.S. 16-17. yüzy1l } \\
\text { (Osmanlı Dönemi) }\end{array}$ \\
\hline Kartal 10 & ETH-44819 & TR-11/05-07 & $\begin{array}{l}\text { Alihoca- Büyük } \\
\text { Toyislam }\end{array}$ & $\begin{array}{l}\text { Eski galeriden } \\
\text { ahşap }\end{array}$ & $600 \pm 30$ & $-23,0 \pm 1,1$ & $\begin{array}{l}\text { M.S. 14-15. yüzy1l } \\
\text { (Osmanl1-Fatih } \\
\text { Sultan Mehmet } \\
\text { Dönemi) }\end{array}$ \\
\hline Kartal 11 & ETH-44820 & TR-11/06-04 & $\begin{array}{l}\text { Madenköy- } \\
\text { Karagümüş }\end{array}$ & Odun kümürü & $835 \pm 30$ & $-22,6 \pm 1,1$ & $\begin{array}{l}\text { M.S. 12. yüzyıl } \\
\text { (Bizans dönemi) }\end{array}$ \\
\hline Kartal 12 & ETH-44821 & TR-11/08-02 & Madenköy & Odun kömürü & $860 \pm 30$ & $-23,0 \pm 1,1$ & $\begin{array}{l}\text { M.S. 12. yüzyıl } \\
\text { (Bizans dönemi) }\end{array}$ \\
\hline
\end{tabular}

Not: ${ }^{14} \mathrm{C}$ yaşı (günümüzden önce) delta ${ }^{13} \mathrm{C}$ düzeltilmiş radyokarbon yaşıdır. $\mathrm{BP}=$ Günümüzden (1950) önce; Delta ${ }^{13} \mathrm{C}$ değeri grafitten ölçülmüş olup ilave fraksiyon içerebilir; Kalibre ${ }^{14} \mathrm{C}$ yaşları (Takvim zaman aralıkları) OxCal v3.10 kullanılarak ölçülmüştür; Bilgi: referanslar ve atmosferik veri Reimer ve diğ. (2009)'dan alınmış, OxCal v3.10 Bronk Ramsey (2009)'dan.

Note: ${ }^{14} \mathrm{C}$ age $(\mathrm{BP})$ delta ${ }^{13} \mathrm{C}$ corrected radiocarbon age; $\mathrm{BP}=$ Before Present (before $1950 \mathrm{AD}$ ); Delta ${ }^{13} \mathrm{C}$ is a value measured on graphite and might include additional fractionation; Calibrated $\mathrm{C}^{14}$ ages (Calendar time intervals) using OxCal v3.10; INFORM : References - Atmospheric data from Reimer ve diğ., (2009); OxCal v3.10 Bronk Ramsey (2009) 


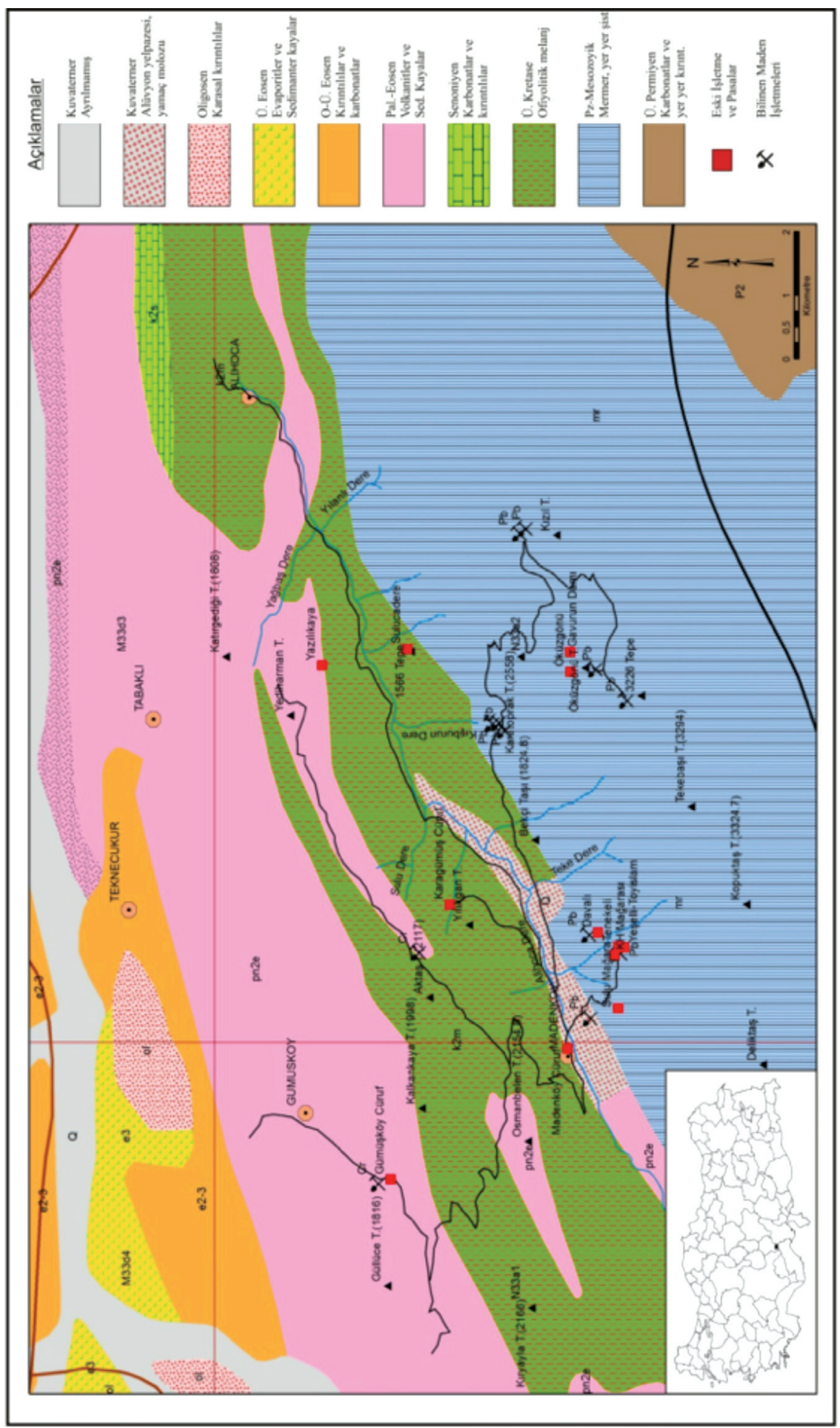

Şekil 1. Bolkar Dağı bölgesinin genel jeolojik özellikleri, eski maden işletmeleri ile cüruf sahalarının konumları (MTA, 2002'den sadeleştirilerek düzenlenmiştir).

Figure 1. General geological features of Bolkar Mountain region and locations of the ancient mines and slag sites (simplified from MTA, 2002). 


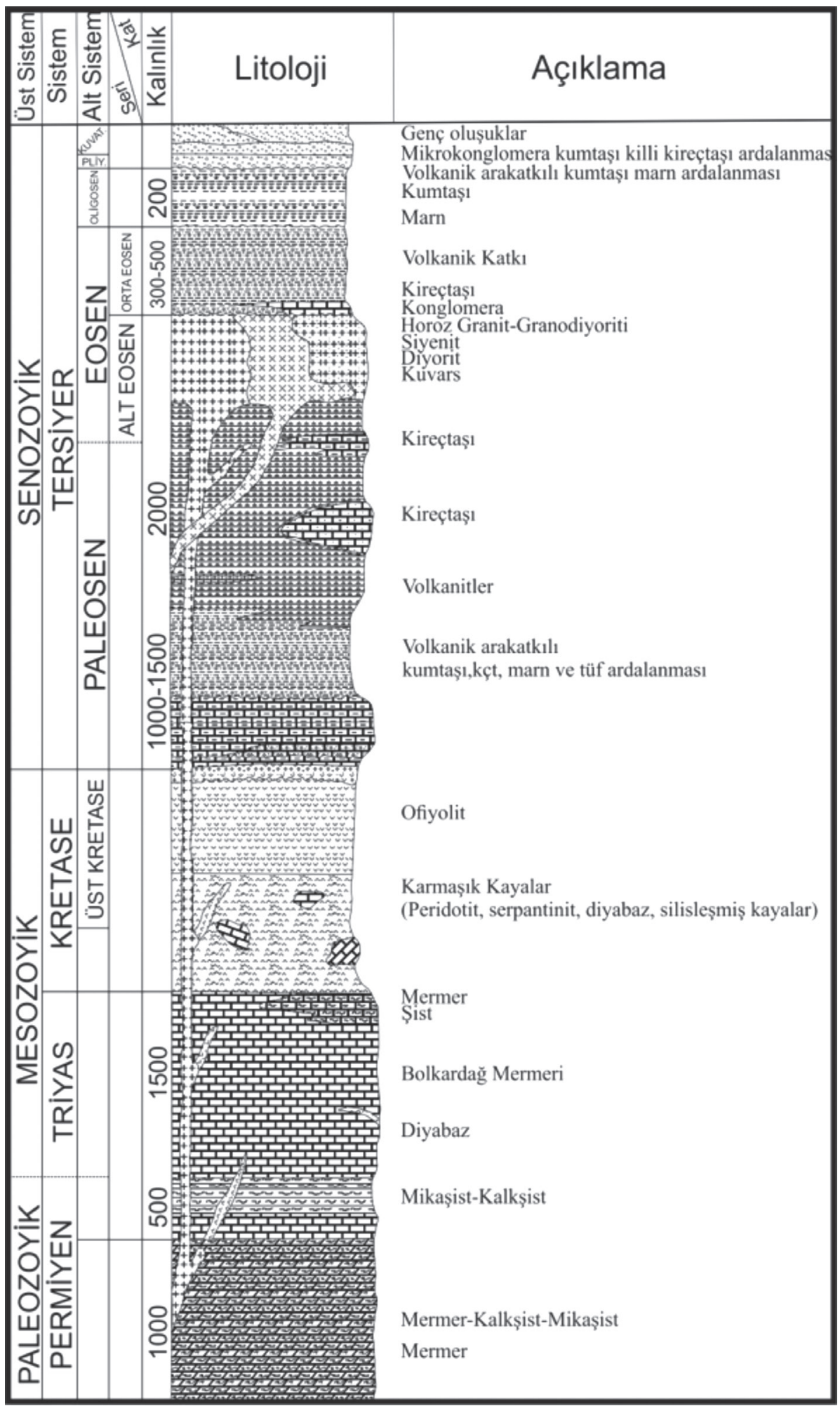

Şekil 2. Bolkardağ yöresi genelleştirilmiş dikme kesiti (Şişman ve diğerleri,1981'den).

Figure 2. Generalized column section of Bolkardă̆ region (after Şişman et al., 1981). 


\section{SAHANIN MADEN JEOLOJISI}

\section{Cüruf Sahalart}

Bolkardağları vadisinde serpinti halinde birçok cüruf yığını ve birikintisinin yanında üç önemli cüruf sahası bulunmaktadır. Bunlar Maden Köyü, Gümüşköy ve Maden Köyü-Karagümüş Mevkii $\mathrm{Pb}-\mathrm{Zn}-\mathrm{Cu}-\mathrm{Au}$ ve Ag cüruf sahalarıdır (Şekil 2).

\section{Madenköyü Pb-Zn-Cu-Au ve Ag cüruf sahast}

Maden köyü cüruf sahasında (Şekil 3A) birçok araştırmacı farklı zamanlarda değişik çalışmalar yapmıştır. Birbirinden oldukça farklı rezerv ve tenörlerin varlığ1 ileri sürülmüştür.1888-1907 y1llar1 arasinda 26.518 ton cevherin izabe edilip 5.693 ton $\mathrm{Pb}, 178.5 \mathrm{~kg} \mathrm{Au}$ ve $24.346 \mathrm{~kg} \mathrm{Ag}$ elde edildiği belirtilmiştir (Yener, 1938). 1974 yılında cüruf rezervine yönelik yapılan ayrıntılı bir çalışmada Maden köyü cüruflarının ortalama derinliği 3,46 m olarak alınmış ve 96,766 ton cürufun varlığı ortaya konmuştur (Balçık, 1974). Cüruflardan alınan numunelerin yapılan kimyasal analizlerinde ortalama \% 2,45 Zn, \% 0,12 Cu, \% $6,85 \mathrm{~Pb}$ ve \% 0,01 Ag nin varlığ bildirilmiştir (Balçık, 1974). Maden köyü cüruf sahasındaki cüruflardan tarafimızca alınan numunelerin yapilan kimyasal analizlerinde $0,8 \mathrm{~g} / \mathrm{t}$ Au ve 142,1 g/t Ag nin varlığı saptanmıştır. (Çizelge 2).
Eski dönemlerde cevherler ağaç ya da odun kömürleriyle ergitildiğinden cürufların bünyelerinde kalan kömürleşmiş odun parçaları işlemin yapıldığı dönemin yaşını kesin olarak belirtmektedir. Maden köyü $\mathrm{Pb}-\mathrm{Zn}-\mathrm{Cu}-\mathrm{Au}$ ve $\mathrm{Ag}$ cüruf sahasında alınan cürufların bünyelerinde bulunan odun kömürlerinden yapılan $\mathrm{C}^{14}$ yaş tayininde $860 \pm 30$ yıl yaş aralığı gelmiştir (Çizelge 1, No. 12). Bu yaş aralığı M.S. 12.yy.'a yani Bizans Dönemine denk gelmektedir.

\section{Gümüşsöy Pb-Zn-Cu-Au ve Ag cüruf sahast}

Eski çağlardan bu yana yapılan çalışmalarda, yaklaşık 9.000 hektarlık bir alanı kapsayan ve içinde eski işletmelerin bulunduğu (Büyük Toyislam, Küçük Toyislam, Yeşelli, Suluca Mağara, Karagöl Mevkii vs.) sahalardan elde edilen cevherlerin yaklaşı $4 \mathrm{~km}$ uzakta bulunan Gümüşköy'e hayvan sırtında taşınarak odun kömürü ile izabe edildiği düşünülmektedir (Şekil 3B). Zira Gümüşköy cüruf sahasının yakınında herhangi bir eski işletme ya da galeri bulunmamaktadır.

Daha önceleri yapılan çalışmalar sonunda yazılan raporlarda, Gümüşköy'de toplam 623.000 ton cürufun bulunduğu belirtilmektedir (Balç1k, 1974). Ancak şu anda 300.000-400.000 ton kadar

Çizelge 2. Madenköy cüruf sahasından alınan cürufların kimyasal analiz sonuçları.

Table 2. Chemical analysis results of the salags of Madenköy region.

\begin{tabular}{|l|l|l|l|l|l|l|l|l|l|l|}
\hline $\begin{array}{l}\text { Ana element } \\
\text { oksitler } \\
\text { Major Elemen } \\
\text { Oxides }\end{array}$ & $\% \mathrm{SiO}_{2}$ & $\begin{array}{l}\% \\
\mathrm{Al}_{2} \mathrm{O}_{3}\end{array}$ & $\begin{array}{l}\% \\
\mathrm{Fe}_{2} \mathrm{O}_{3}\end{array}$ & $\begin{array}{l}\% \\
\mathrm{CaO}\end{array}$ & $\% \mathrm{MgO}$ & $\% \mathrm{Na}_{2} \mathrm{O}$ & $\% \mathrm{~K}_{2} \mathrm{O}$ & $\% \mathrm{TiO}_{2}$ & $\% \mathrm{P}_{2} \mathrm{O}_{5}$ & $\% \mathrm{MnO}$ \\
\hline $\begin{array}{l}\text { Cüruf } \\
\text { Slag }\end{array}$ & 35,63 & 3,36 & 39,02 & 4,63 & 1,55 & 0,11 & 0,62 & 0,21 & 0,11 & 1,13 \\
\hline $\begin{array}{l}\text { Baz ve değerli } \\
\text { metaller } \\
\text { Base and Precious } \\
\text { Metals }\end{array}$ & $\% \mathrm{PbO}$ & $\begin{array}{l}\% \\
\mathrm{ZnO}\end{array}$ & $\% \mathrm{CuO}$ & $\% \mathrm{As}_{2} \mathrm{O}_{3}$ & $\begin{array}{l}\% \\
\mathrm{Sb}_{2} \mathrm{O}_{3}\end{array}$ & $\begin{array}{l}\% \\
\mathrm{Cr}_{2} \mathrm{O}_{3}\end{array}$ & $\begin{array}{l}\% \\
\mathrm{SnO}_{2}\end{array}$ & $\begin{array}{l}\mathrm{Au} \\
(\mathrm{g} / \mathrm{t})\end{array}$ & $\mathrm{Ag}(\mathrm{g} / \mathrm{t})$ & $\% \mathrm{PbO}$ \\
\hline \begin{tabular}{l} 
Süruf \\
\hline
\end{tabular} & 10,40 & 1,73 & 0,11 & 0,57 & 0,13 & 0,08 & 0,10 & 0,8 & 142,1 & 10,40 \\
\hline
\end{tabular}


cüruf kalmıştır (Şekil 3B). Daha önceki çalışmalar sırasında bu cüruflardan yapılan analizlerde ort. \% 4,85 Pb, \% 2,84 Zn, \% 0,14 Cu, 43 g/t Ag değerleri elde edilmiştir (Balçık, 1974). Çalışmalarımız sırasında yapılan kimyasal analizler de $0,9 \mathrm{~g} / \mathrm{t} \mathrm{Au}$ ve $67,9 \mathrm{~g} / \mathrm{t}$ Ag değerleri elde edilmiştir. Konyalı bir kuyumcu cüruflardan $\mathrm{Au}$ ve $\mathrm{Ag}$ elde etmek için burada bir işletme kurmuş bir müddet üretim yaptıktan sonra işletmeyi terk etmiştir (Şekil 3C). Bir tanesi toz halinde öğütülmüş olan iki ayrı cüruf örneğinin kimyasal analiz sonuçları Çizelge 3 'de verilmiştir.

Çizelge 3. Gümüşköy cüruf sahasından alınan cüruf ve öğütülmüş cürufun kimyasal analiz sonuçları.

Table 3. Chemical analysis results of the salags and grinded slags of Gümüşköy region.

\begin{tabular}{|c|c|c|c|c|c|c|c|c|c|c|}
\hline $\begin{array}{l}\text { Ana element } \\
\text { oksitler } \\
\text { Major Elemen } \\
\text { Oxides }\end{array}$ & $\begin{array}{l}\% \\
\mathrm{SiO}_{2}\end{array}$ & $\begin{array}{l}\% \\
\mathrm{Al}_{2} \mathrm{O}_{3}\end{array}$ & $\% \mathrm{Fe}_{2} \mathrm{O}_{3}$ & $\begin{array}{l}\% \\
\mathrm{CaO}\end{array}$ & $\% \mathrm{MgO}$ & $\% \mathrm{Na}_{2} \mathrm{O}$ & $\% \mathrm{~K}_{2} \mathrm{O}$ & $\% \mathrm{TiO}_{2}$ & $\% \mathrm{P}_{2} \mathrm{O}_{5}$ & $\begin{array}{l}\% \\
\mathrm{MnO}\end{array}$ \\
\hline $\begin{array}{l}\text { Cüruf } \\
\text { Slag }\end{array}$ & 25,26 & 2,80 & 48,36 & 6,05 & 1,36 & 0,13 & 0,69 & 0,15 & 0,21 & 0,48 \\
\hline $\begin{array}{l}\text { Öğ̈utülmüş cüruf } \\
\text { Grinded Slag }\end{array}$ & 24,18 & 3,45 & 51,21 & 6,91 & 1,55 & 0,20 & 0,78 & 0,19 & 0,19 & 0,61 \\
\hline $\begin{array}{l}\text { Baz ve değerli } \\
\text { metaller } \\
\text { Base and Precious } \\
\text { Metals }\end{array}$ & $\begin{array}{l}\% \\
\mathrm{PbO}\end{array}$ & $\% \mathrm{ZnO}$ & $\begin{array}{l}\% \\
\mathrm{CuO}\end{array}$ & $\% \mathrm{As}_{2} \mathrm{O}_{3}$ & $\% \mathrm{Sb}_{2} \mathrm{O}_{3}$ & $\% \mathrm{Cr}_{2} \mathrm{O}_{3}$ & $\% \mathrm{SnO}_{2}$ & $\begin{array}{l}\mathrm{Au} \mathrm{g} / \\
\text { ton }\end{array}$ & $\begin{array}{l}\text { Ag g/ } \\
\text { ton }\end{array}$ & \\
\hline $\begin{array}{l}\text { Cüruf } \\
\text { Slag }\end{array}$ & 8,44 & 2,12 & 0,24 & 1,89 & 0,20 & 0,02 & 0,10 & 0,9 & 67,9 & \\
\hline $\begin{array}{l}\text { Öğ̈ütülmüş cüruf } \\
\text { Grinded Slag }\end{array}$ & 4,31 & 2,85 & 0,18 & 1,65 & 0,10 & 0,05 & 0,07 & $\mathrm{G}$ & 42,4 & \\
\hline
\end{tabular}

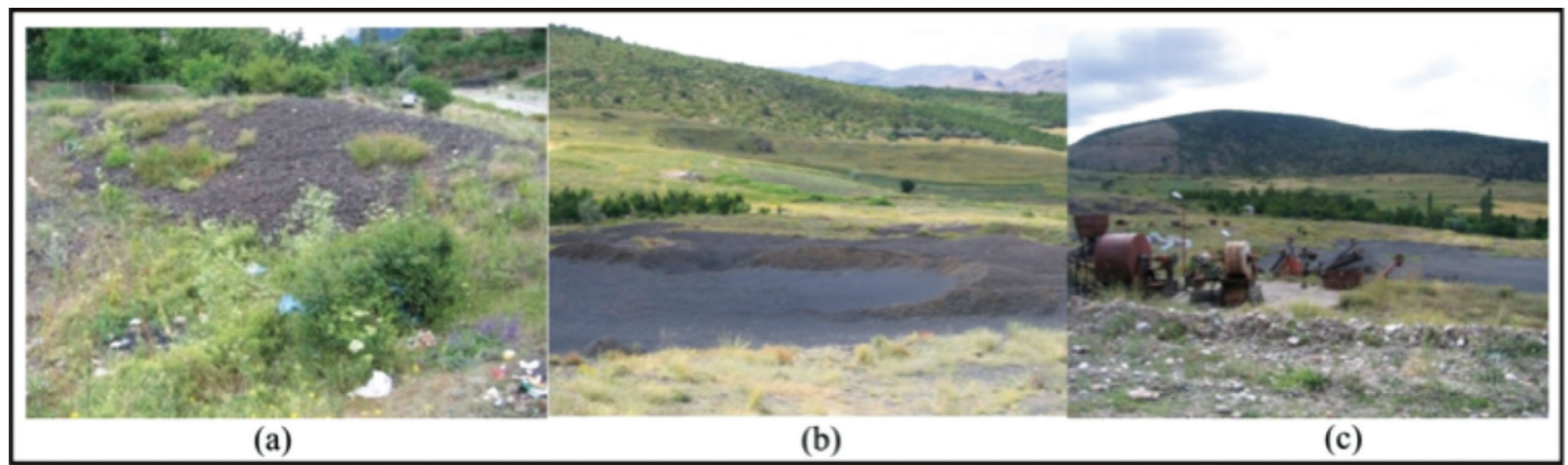

Şekil 3. a) Madenköy cüruf sahasının genel görünümü, b) Gümüşköy cüruf sahasında genel görünüm, c) Gümüşköy cüruf sahasında bulunan cüruflardan $\mathrm{Au}$ ve $\mathrm{Ag}$ elde etmek için kurulan öğütme tesisinden genel görünüm.

Figure 3. General view of the slag monds of: a) Madenköy, b) Gümüşköy, and c) Grinding facility in Gümüssköy slag area. 
Maden Köyü-Karagümüs Mevkii Pb-Zn-Cu-Au ve Ag cüruf sahası

İlk defa tarafimızdan tespit edilen ve literatüre geçen bir $\mathrm{Pb}-\mathrm{Zn}-\mathrm{Cu}-\mathrm{Au}$ ve $\mathrm{Ag}$ cüruf sahasıdır (Şekil4A). Saha örtülü olduğu için devamlılığ 1 görülememiştir. Yaklaşık 15.000-20.000 ton cüruf mevcuttur. Sahada eski işletmelere ait olabilecek seramik parçası, kırma-öğütme taşı, taş, havan veya firın parçaları da bulunamamıştır. Cevherin bir başka yerden buraya getirilerek odunlarla ergitilip, izabe edildiği düşünülmektedir. Zira sahanın yakın çevresinde herhangi bir eski işletme galerisi ya da cevherleşme bulunmamaktadır. İşletmenin yapıldığı dönemde burada bulunan orman ve su kaynaklarından yararlanıldı $\breve{g} 1$ düşünülmektedir. Sahadaki cürufların bünyesinde bulunan odun kömüründen yapilan $\mathrm{C}^{14}$ yaş analizi sonucunda $835 \pm 30$ y1l (M. S. 12-13. yüzyıl) değerleri elde edilmiştir(Çizelge 1, No. 11). Bu yaş aralığı bize Bizans Dönemi'ni işaret etmektedir. Cüruflardan yapılan kimyasal analiz sonuçlarına göre cürufların bünyelerinde $1,3 \mathrm{~g} / \mathrm{t}$ Au ve $92,8 \mathrm{~g} / \mathrm{t}$ Ag varlığı tespit edilmiştir (Çizelge 4).

Çizelge 4. Madenköy- Karagümüş mevkii cüruf sahasından alınan cürufların kimyasal analiz sonuçları.

Table 4. Chemical analysis of the slags of Madenköy-Karagümüş area.

\begin{tabular}{|l|l|l|l|l|l|l|l|l|l|l|}
\hline $\begin{array}{l}\text { Ana element } \\
\text { oksitler } \\
\begin{array}{l}\text { Major Elemen } \\
\text { Oxides }\end{array}\end{array}$ & $\begin{array}{l}\% \\
\mathrm{SiO}_{2}\end{array}$ & $\% \mathrm{Al}_{2} \mathrm{O}_{3}$ & $\% \mathrm{Fe}_{2} \mathrm{O}_{3}$ & $\% \mathrm{CaO}$ & $\% \mathrm{MgO}$ & $\% \mathrm{Na}_{2} \mathrm{O}$ & $\% \mathrm{~K}_{2} \mathrm{O}$ & $\% \mathrm{TiO}_{2}$ & $\% \mathrm{P}_{2} \mathrm{O}_{5}$ & $\% \mathrm{MnO}$ \\
\hline $\begin{array}{l}\text { Cüruf } \\
\text { Slag }\end{array}$ & 23,89 & 2,63 & 55,64 & 4,54 & 1,08 & 0,10 & 0,61 & 0,15 & 0,12 & 0,59 \\
\hline $\begin{array}{l}\text { Baz ve değerli } \\
\text { metaller } \\
\text { Base and } \\
\text { Precious } \\
\text { Metals }\end{array}$ & $\begin{array}{l}\% \\
\mathrm{PbO}\end{array}$ & $\begin{array}{l}\mathrm{ZnO} \\
\text { Cüruf } \\
\text { Slag }\end{array}$ & $\% \mathrm{CuO}$ & $\begin{array}{l}\% \\
\mathrm{As}_{2} \mathrm{O}_{3}\end{array}$ & $\% \mathrm{Sb}_{2} \mathrm{O}_{3}$ & $\% \mathrm{Cr}_{2} \mathrm{O}_{3}$ & $\% \mathrm{SnO}_{2}$ & $\mathrm{Au}(\mathrm{g} / \mathrm{t})$ & $\mathrm{Ag}(\mathrm{g} / \mathrm{t})$ & \\
\hline
\end{tabular}

\section{Eski İşletmeler}

Bolkar Dağları'nda 30'a yakın eski işletme ve cüruf sahası bulunmaktadır. Bunlardan girilebilen sekiz eski işletme kayıt altına alınabilmiştir. Bunlar Yeşelli - Toyislam, Sulucadere, Öküzgönü, Tenekeli Mağarası, KA-A(Kh) mağarası, Sulu Mağara, Davalı Mevkii ve Gavurun Damı eski işletmeleridir (Şekil 1). Bu eski işletmeler içinde Yeşelli-Toyislam ve Gavurun Damı işletmeleri oldukça önemlidir. Eski araştırmalar ve Bolkardağ madenleri civarlarındaki yazıtlar, buradaki madenlerin M.Ö 800 den bu yana belli aralıklarla işletildiğini göstermektedir. Önceleri Hititler daha sonra da Romalılar tarafından madenin işletildiği sanılmaktadır (Hannbert, 1888). Bolkardağ madencileri ile ilgili en eski rapor, Beral (1865) tarafindan yazılmıştır. Raporda madenler ve civarının jeolojisinden bahsedilmektedir. Madenlerin 1825 yılından beri çalıştığını, yılda ortalama 1000 ton cevher çıkartıldığını, 1863 'te beş ve 1864 'te on ocakta işletme yapıldığını, üretilen cevherin yaklaşı $\% 21 \mathrm{~Pb}, 428 \mathrm{~g} / \mathrm{t} \mathrm{Ag}, 40 \mathrm{~g} / \mathrm{t} \mathrm{Au}$ tenörlü olduğunu ve Madenköy'de bulunan onüç adet manşlı firın ile dört adet Küpelasyon firınında izabe edildiğini belirtmektedir. Wartheman (1888), 1870-1887 yılları arasında, her yıl yaklaşık 2250 ton cevher izabe edildiğini; Cokino (1927) Bolkar 
madenlerindeki işletme çalışmalarının 1912 yılında Balkan Savaşı sırasında devlet tarafından durdurulduğunu ifade etmektedir.

Cumhuriyetin kuruluşundan sonraki dönemlerde bölgedeki madenin işletilmesi için bir kaç defa girişimlerde bulunulmuştur. 19271928 senelerinde maden üzerinde ayrıntılı jeoloji çalışmaları yapılarak işletme tesisleri kurulması önerilen fabrika planları hazırlanmıştır(Ralli, 1928; Helke, 1929). 1935 yılından itibaren Bolkardağ madenlerinde M.T.A Enstitüsü araştırmalara başlamıştır. 1935-1938 yılları arasında Bolkardağ sahasında Yeşelli, Küçük Toyislam, Keçili, Davalı, Sirostat ve Timyos mağaralarında bulunan cevherlerin rezerv hesapları yapılmış, işletme galerileri açılmıştır (Romberg,1937; Hummel, 1938; Oelsner, 1938).

1939 y1lında Bolkardağ- I ve II sahası Etibank'a devredilmiştir. 1939-1942 y1lları arasında Bolkardağ-I ve II sahasında incelemeler sürdürülerek cevherlerin rezerv hesapları yapılmıştır (Kovenko, 1942; Ajoukiewichz, 1946). Ancak, II. Dünya Savaşı'nın çıkması ile madenin işletilmesine başlanamamıştır. Daha sonra, günümüze dek pek çok araştırmacı gerek jeoloji gerekse madencilik açısından bölgede incelemeler yapmıştır. Son olarak M.T.A Enstitüsü ve Etibank ortak bir proje halinde 1976 yılında Bolkardağ bölgesinde ayrıntılı araştırmalara başlamış, $\mathrm{Pb}$ $\mathrm{Zn}$ cevherleşmesi bakımından önemli olduğu düşünülen ve saptanan yeni sahalarda jeoloji ve jeofizik incelemeler tamamlanmış ve bu sahalarda araştırma sondajları yapılmıştır (Şişman ve diğerleri, 1981).

MTA’nın Jeoloji çalışmalarını yaptığı ve sondajlarla rezervini tespit ettiği bu saha Etibank'a devredilmiştir. Etibank sahayı işlettikten sonra verimli olmadığı gerekçesiyle terk etmiştir. Günümüzde özel sektöre ait Gümüştaş A.Ş’ye geçen saha da altına yönelik üretim çalışmaları yapılmaktadır. 2011 y1lı itibariyle toplam 5000 $\mathrm{m}$ galeri sürülerek alınan cevher UlukışlaTepeköy'e taşınarak burada kurulacak fabrikada değerlendirilecektir. Çalışan teknik elemanlardan gayri resmi olarak edinilen bilgilere göre cevherin ortalama $10 \mathrm{~g} / \mathrm{t}$ Au ve $300 \mathrm{~g} / \mathrm{t} \mathrm{Ag} \mathrm{içerdiği} \mathrm{ifade}$ edilmiştir.

\section{Yeşelli-Büyük Toyislam sahası}

Geçmiş dönemlerde işletilmiş olan ve Bolkar Dağları'nda bulunan en büyük işletme galerisi olup Yeşelli ile Büyük Toyislam galerileri birarada işletilmektedir. Günümüzde özel sektör tarafından işletilen Yeşelli-Büyük Toyislam sahasının galeri girişinden itibaren (Şekil 4B) yaklaşık 2 km'lik mesafeyi arabayla geçtikten sonra Büyük Toyislam sahasına, eski işletmeciler tarafından açılmış olan galerilerden girilmiştir. Bu galeri içinde cevher damarı (Şekil 4C), eski dönem işletmecileri tarafından yapılmış yapay taş merdivenler (Şekil 5A), sahanlıklar (Şekil 5B), eski üretim izlerini gösteren murç izleri (Şekil 5C) tespit edilmiştir. 


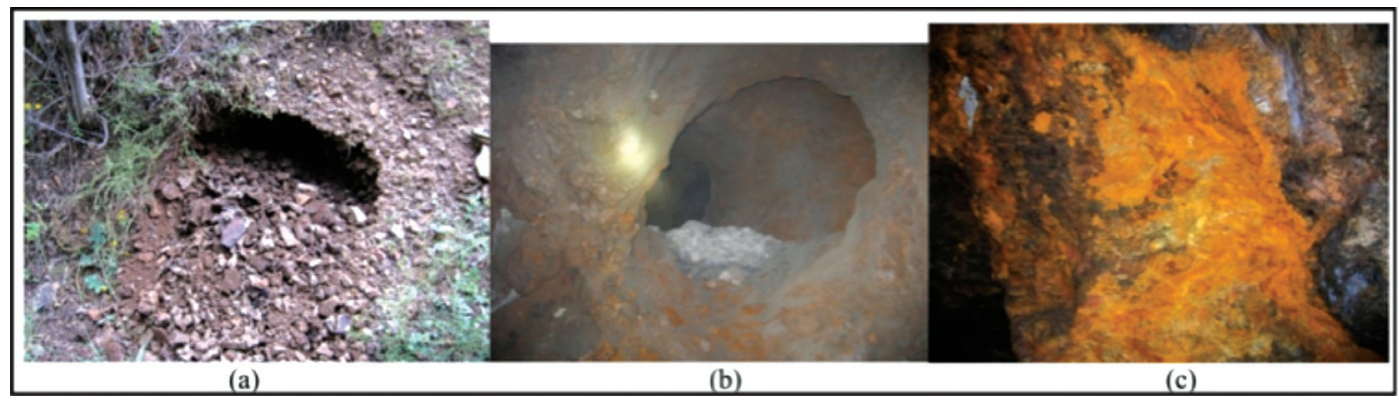

Şekil 4. a) Madenköy-Karagümüş Mevki Cüruf sahasının genel görünüm, b) Yeşelli-Büyük Toyislam galerisinin giriş ağzından görünüm, c) Yeşelli-Büyük Toyislam galerisi içindeki cevher damarı.

Figure 4. General view of slag mound of Madenköy-Karagümüş area, b) Entrance of the drift of Yeşelli-Toyislam, c) ore vein of Yeşelli-Toyislam drift.

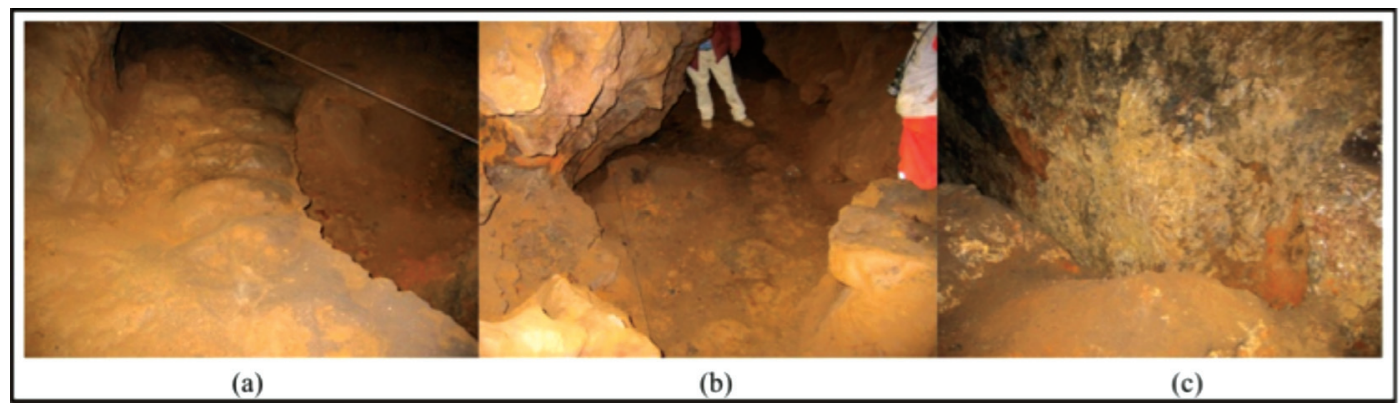

Şekil 5. a) Yeşelli-Büyük Toyislam Galerisi içerisindeki yapay taş merdiven, b) Yeşelli-Büyük Toyislam galerisinin içindeki sahanlık ve yapay taş merdivenler, c) Yeşelli-Büyük Toyislam galerisinin içinde bulunan ve eski çağlarda işletildiğini gösteren murç izleri.

Figure 5. a) Artificial caved stair; b) stairhead and stairs; and c) bush hammer prints in the Yeşelli-Toyislam drift.

Büyük Toyislam galerisi içerisinde (Şekil6A). Aynı galeride işçiler tarafından bulunan aydınlatmada kullanılan, muhtemelen Geç ve cevher üretimi hesaplanmasında kullanılan bir Osmanlı Dönemine ait bir sırlı kandil bulunmuştur abaküs (Şekil 6B) görülerek resmedilmiştir.

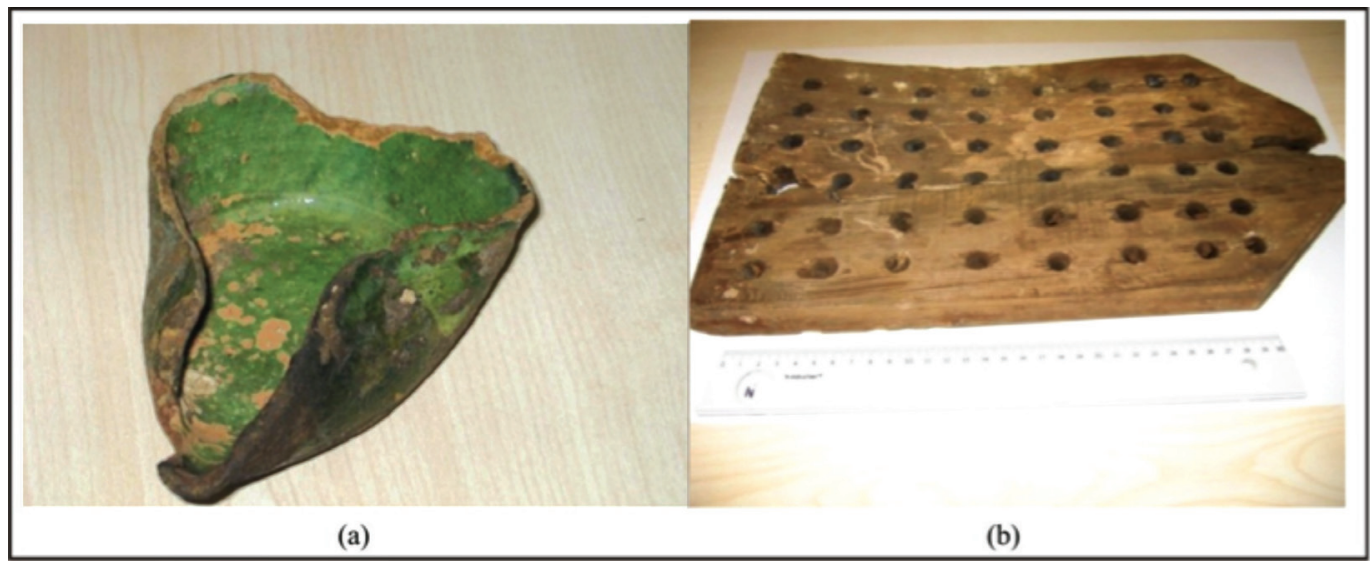

Şekil 6. a) Yeşelli-Büyük Toyislam Galerisi içerisinde bulunan ve aydınlatmada kullanılan, muhtemelen Geç Osmanlı Dönemine ait sırlı kandil, b) Yeşelli-Toyislam galerisi içerisinde bulunan ve cevher hesaplamasında kullanılan abaküs.

Figure 6. a) glazed lamp of Ottoman Empire period, and b) abacus discoveries in the Yeşelli-Büyük Toyislam drift. 
Büyük Toyislam'da bulunan eski kesin bir sonuçtur. Küçük su teknesinin (Şekil galerilerden $\mathrm{C}^{14}$ analizi için tahkimat parçaları alınmıştır. Yeşelli sahasının galerilerinde bulunan 1 adet beton dökme taş levha (Şekil 7A) ile ahşap kürekler (Şekil 7B) MTA Tabiat Tarihi Müzesi'nde sergilenmek üzere Müze Müdürlüğü'ne teslim edilmiştir.Yeşelli galerisinde bulunan biri büyük (Şekil 7C), diğeri küçük (Şekil 8A) iki adet su teknesi aynı şekilde MTA Tabiat Tarihi Müzesi'nde sergilenmek üzere getirilmiştir. $\mathrm{Bu}$ su teknelerinden büyük su teknesinin (Şekil 7C) $\mathrm{C}^{14}$ yaş analizine göre yaşı $1000 \pm 30$ yıl'dır (Çizelge 1, No. 2). Bu sonuç sahanın M.S. 10-11. yüzyılda Bizanslılar Dönemi’nde işletildiğini gösteren $8 \mathrm{~A}$ ) yaşı ise $155 \pm 30$ yıl olarak gelmiştir (Çizelge 1, No. 3). Bu yaş aralığı da sahanın Osmanlıların son dönemlerinde (II.Mahmut ve II.Abdülhamit dönemlerinde) işletildiğini göstermektedir. Aynı galeride bulunan ahşap küreklerden yeni olanın (Şekil 7B) $C^{14}$ yaş1 $125 \pm 30$ yıl olup (Çizelge 1, No. 8), 19. yüzyıl başlarını yani Osmanlıların son dönemini işaret etmektedir. Eski olan ahşap küreğin (Şekil 7B) $\mathrm{C}^{14}$ yaşı ise $1000 \pm 30$ yıl olarak tespit edilmiştir (Çizelge 1, No. 7). Bu veri, Yeşelli-Büyük Toyislam işletmesinin M.S. 11.yüzyıllarında, o dönemde buraya hakim olan Bizanslılar tarafından işletildiğini göstermektedir.

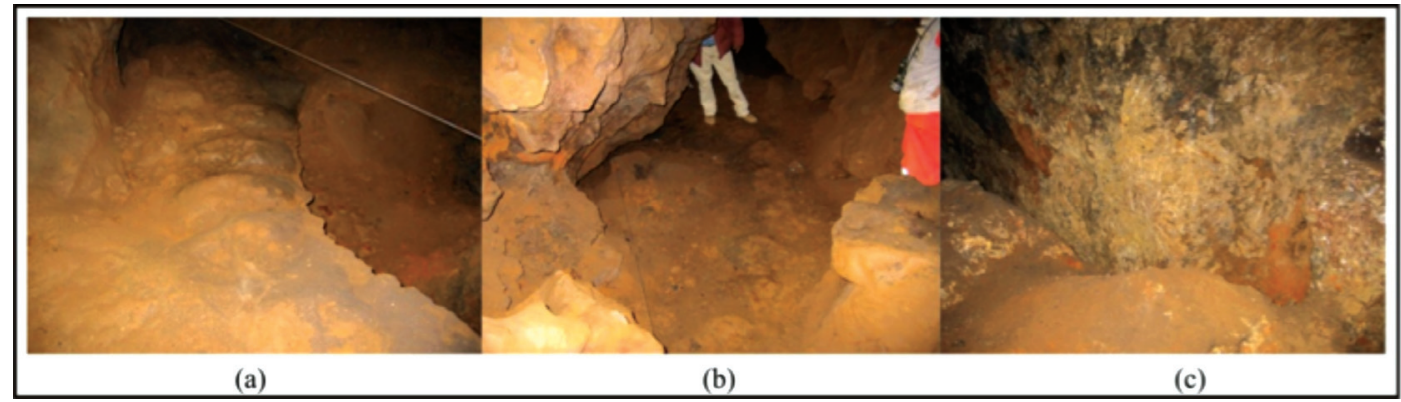

Şekil 7. a) Yeşelli sahasının galerisinde bulunan dökme betondan yapılmış Madenci Amblemi, b) Yeşelli-Toyislam Galerisi içerisinde bulunan eski ve yeni ahşap kürekler, c) Yeşelli-Büyük Toyislam Galerisi içerisinde bulunan Büyük Su Teknesi.

Figure 7. a) Mining symbol from concrete in Yeşelli drift, b) ancient and recent shovels in Yeşelli-Toyislam drift, c) big water vessel in Yeşelli-Büyük Toyislam drift.

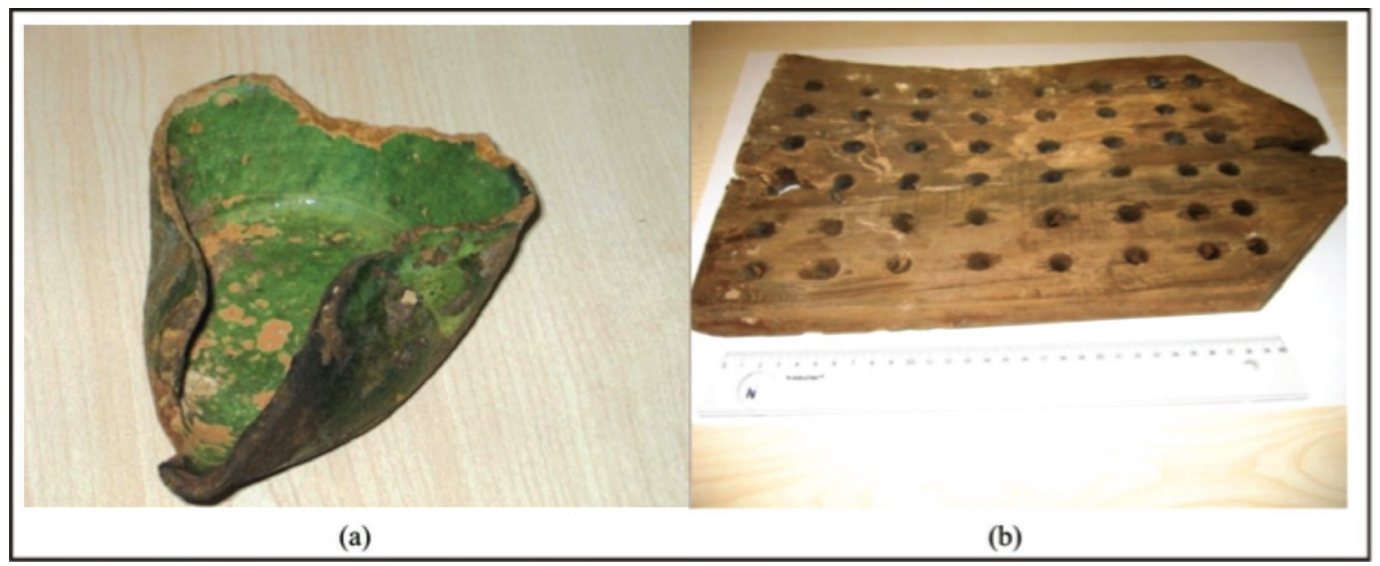

Şekil 8. a) Yeşelli-Büyük Toyislam Galerisi içerisinde bulunan Küçük Su Teknesi, b) Yeşelli-Büyük Toyislam galerisi içinde bulunan ağaç tahkimatlar.

Figure 8. a) Small water vessel, and b) wooden fortifications in Yeşelli-Büyük Toyislam drift. 
Ağaç tahkimatların (Şekil 8B) $\mathrm{C}^{14}$ analiz sonucu $105 \pm 30$ yıl olarak gelmiştir (Çizelge 1, No. 1). Buna göre saha Osmanlılar Dönemi'nde, II.Abdülhamit zamanında da işletilmiş olmalıdır. Yeşelli galerisinin giriş ağzından $200 \mathrm{~m}$ sonra, Tekebaşı olarak adlandırılan yerde alınan ve oldukça eski görünümde olan ağaç tahkimatın (Şekil 9A) $\mathrm{C}^{14}$ yaşı ise $600 \pm 30 y 1$ olarak tespit edilmiş olup (Çizelge 1, No. 10), M.S. 14.yüzy1lı, yani Fatih Sultan Mehmet dönemini işaret etmektedir. Yine Yeşelli-Büyük Toyislam galerisi içinden alınan çıra parçasının (Şekil 9B) $\mathrm{C}^{14}$ yaşı $385 \pm 30$ olarak gelmiştir (Çizelge 1, No. 9). Bu analiz sonucu, çıranın 16.yüzyıla ait olduğunu yani Osmanlı Dönemi’nde bu işletmede üretimin yapıldı̆̆ını göstermektedir.

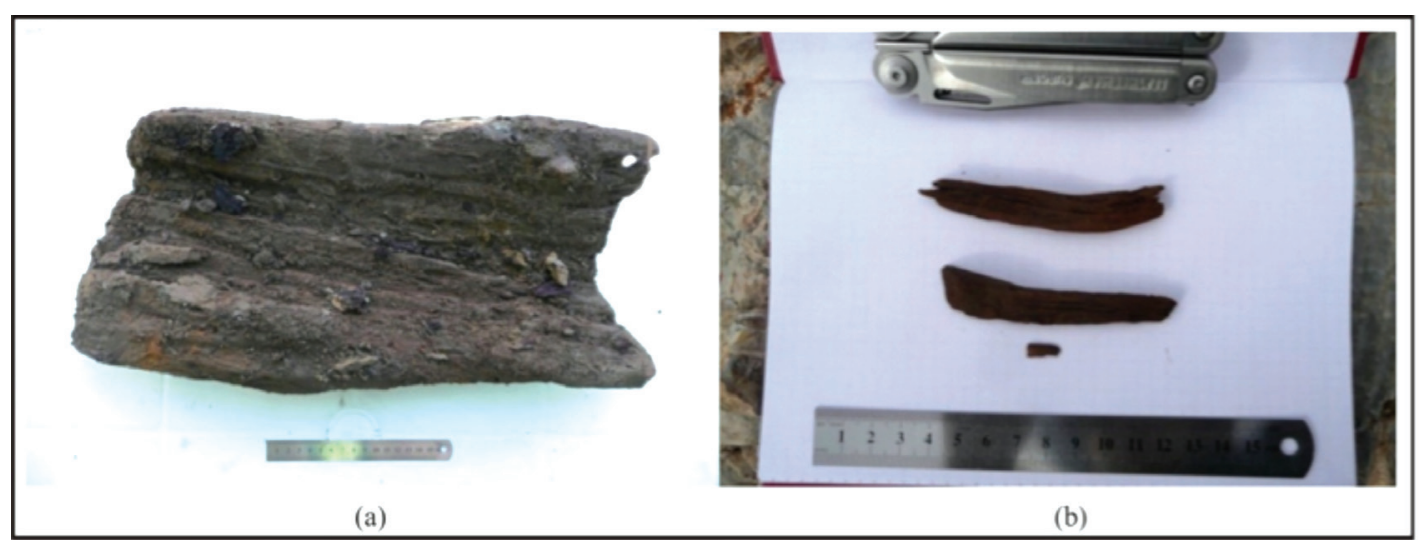

Şekil 9. a) Yeşelli galerisi içinde alınan ağaç tahkimat parçası, b)Yeşelli-Büyük Toyislam galerisi içerisinde alınan çıra parçası.

Figure 9. a) Wooden fortification fragment, and b) firewood fragment from Yeşelli drift

Galeri içindeki cevherden kimyasal analiz için alınan numunenin analiz sonuçları Çizelge 5’te verilmiştir.

Çizelge 5. Yeşelli-Büyük Toyislam Galerisi içindeki cevherden alınan numunenin kimyasal analiz sonuçları.

Table 5. Analysis results of the ore of Yeşelli-Büyük Toyislam drift

\begin{tabular}{|l|l|l|l|l|l|l|l|l|l|l|}
\hline $\begin{array}{l}\text { Numunenin } \\
\text { Cinsi } \\
\text { Type of the sample }\end{array}$ & $\% \mathrm{SiO}_{2}$ & $\begin{array}{l}\% \\
\mathrm{Al}_{2} \mathrm{O}_{3}\end{array}$ & $\begin{array}{l}\% \\
\mathrm{Fe}_{2} \mathrm{O}_{3}\end{array}$ & $\% \mathrm{CaO}$ & $\begin{array}{l}\% \\
\mathrm{MgO}\end{array}$ & $\begin{array}{l}\% \\
\mathrm{Na}_{2} \mathrm{O}\end{array}$ & $\% \mathrm{~K}_{2} \mathrm{O}$ & $\% \mathrm{TiO}_{2}$ & $\% \mathrm{P}_{2} \mathrm{O}_{5}$ & $\% \mathrm{MnO}$ \\
\hline $\begin{array}{l}\text { Cevher } \\
\text { Ore }\end{array}$ & 6,00 & 1,00 & 47,88 & 8,48 & 0,42 & $<0,01$ & 0,12 & 0,04 & 0,04 & 0,54 \\
\hline $\begin{array}{l}\text { Baz ve değerli } \\
\text { metaller }\end{array}$ & $\% \mathrm{PbO}$ & $\% \mathrm{ZnO}$ & $\% \mathrm{CuO}$ & $\begin{array}{l}\% \\
\mathrm{As}_{2} \mathrm{O}_{3}\end{array}$ & $\begin{array}{l}\% \\
\mathrm{Sb}_{2} \mathrm{O}_{3}\end{array}$ & $\begin{array}{l}\% \\
\mathrm{Cr}_{2} \mathrm{O}_{3}\end{array}$ & $\% \mathrm{SnO}_{2}$ & $\begin{array}{l}\mathrm{Au} \\
(\mathrm{g} / \mathrm{t})\end{array}$ & $\begin{array}{l}\mathrm{Ag} \\
(\mathrm{g} / \mathrm{t})\end{array}$ & \\
\hline $\begin{array}{l}\text { Cevher } \\
\text { Base and precious } \\
\text { metals }\end{array}$ & 0,19 & 17,54 & 0,03 & 1,28 & $<0,01$ & $<0,01$ & $<0,01$ & $\mathrm{G}$ & 2,7 & \\
\hline
\end{tabular}




\section{Gavurun Damı sahast}

Sahada eski dönemlerde üretim yapılmış olup, günümüzde özel sektöre ait Gümüştaş A.Ş. sahayı işletmek için yeni yollar açmıştır. Sahada birbirine yakın mesafede iki ayrı galeri bulunmaktadır. Önceki dönemlerde Galeri 1'den girildiğinde Galeri 2’ye çıkıldığı köylülerce ifade edilmiştir. Her iki galerinin arası yaklaşı 250-300 m'dir. Galeri 1'den girilerek (Şekil 10A) yaklaşı 100 $\mathrm{m}$ gittikten sonra, göçükten dolayı daha ileriye gidilememiştir. Eski işletmelerden kalan tahkimat parçaları, ahşap merdiven ve aydınlatmada kullanılan çıra parçasından $\mathrm{C}^{14}$ yaş analizi için numune alınmıştır.

Galeri-2'nin giriş ağzından (Şekil 10B) itibaren verev şekilde karşı1lıklı açılmış oyuklar tespit edilmiştir. Eski işletmecilerin bu oyuklara ağaç tahkimatlar yerleştirerek maden ocağına daha rahat bir şekilde inip-çıkmak için kullandıkları düşünülmektedir (Şekil 11A). Gavurun Damı galeri 1 'in girişinden yaklaşı $100 \mathrm{~m}$ gittikten sonra içerde tespit edilen ahşap merdivenden (Şekil 11B) alınan tahta parçasının yapılan $\mathrm{C}^{14}$ testinde yaşı $135 \pm 30$ yıl olarak saptanmıştır (Çizelge 1, No. 6). Bu da 18. yüzyılları işaret etmekte olup Osmanlı Dönemine karşılık gelmektedir. Aynı galeriden alınan ahşap direğin (Şekil 11C) $\mathrm{C}^{14}$ yaşı $205 \pm 25$ olarak saptanmış olup (Çizelge 1, No. 5), 1750'li yılları, yani Osmanlı Dönemi'ni işaret etmektedir. Galerinin içinde bulunan çıranın $\mathrm{C}^{14}$ yaşı ise $270 \pm 25$ olarak gelmiştir (Çizelge 1, No. 4). Bu da Gavurun Damı işletmesinin 17. yüzyılda, yani Osmanlılar Dönemi’nde işletildiğini gösteren destekleyici bir veridir.

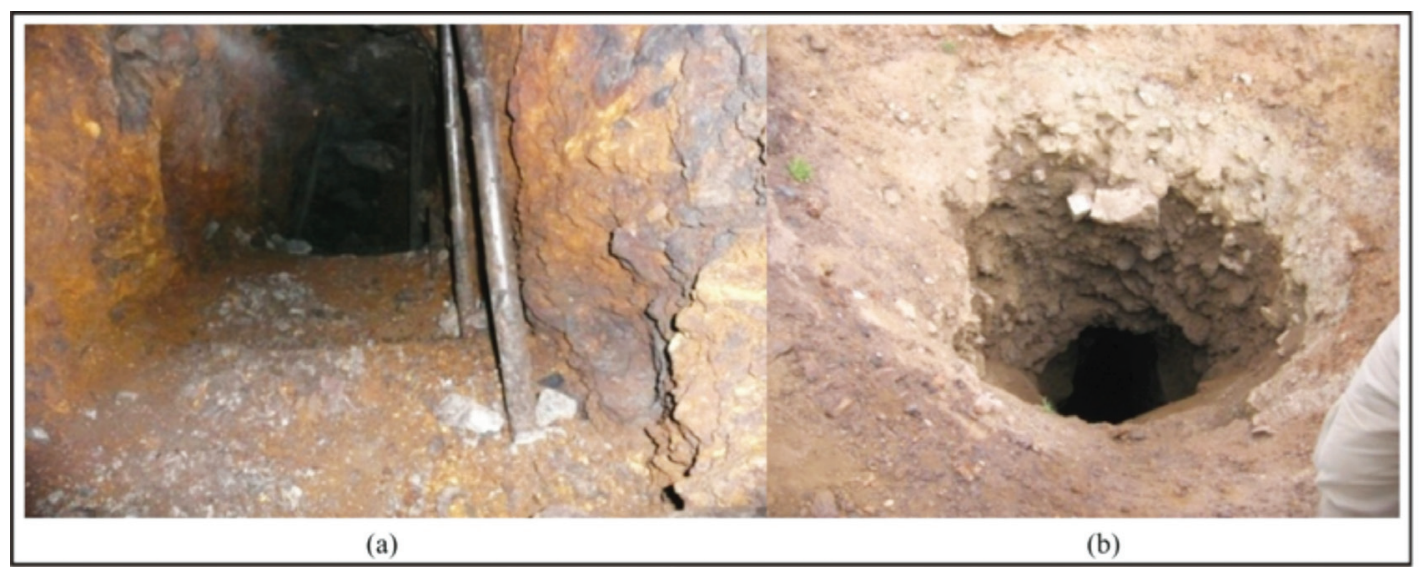

Şekil 10. a) Gavurun Damı Galeri-1' in giriş ağzı, b) Gavurun Damı Galeri-2'nin giriş ağzı.

Figure 10. a) The entrances of the Gavurun Damı adit-1, b)Gavurun Damı adit-2

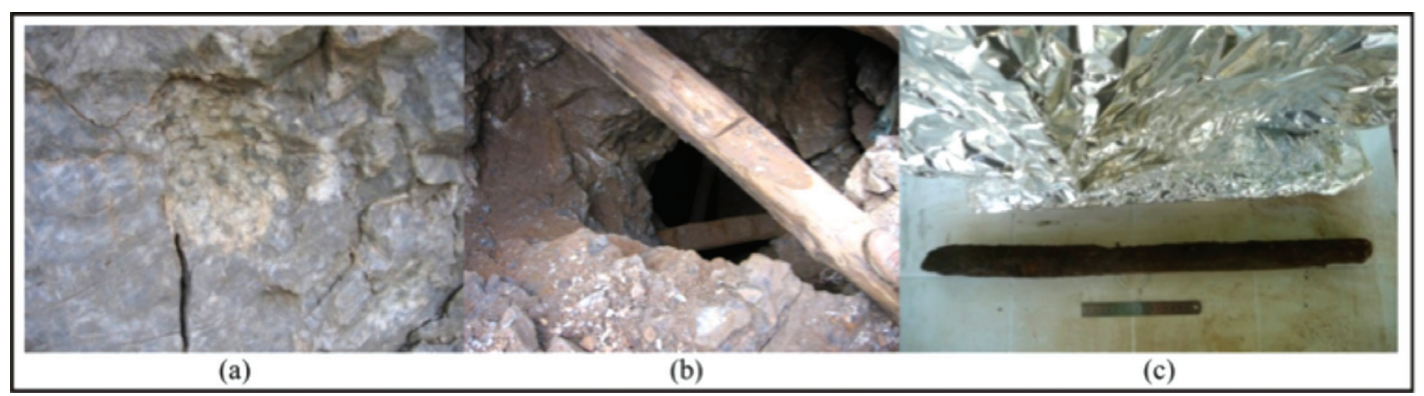

Şekil 11. a) Gavurun Damı Galeri-2 de bulunan ve galeriye inip-çıkmayı kolaylaştıran oyuklar, b) Gavurun Damı galerisi içindeki ahşap merdivenler, c) Gavurun Damı Galerisinden alınan ahşap direğin görünümü.

Figure 11. a) Artificial cavities to easify to go up and down in the drift-2 in Gavurun Damı area, b) wooden pole from Gavurun Damı drift 


\section{ÍLK MADEN RUHSATI: YAZILITAŞ}

Bolkardağ ile ilgili en somut kaynak, Neo-Hitit dönemine tarihlenen 5 satırlık hiyeroglif bir yazıttır. Alihoca köyünün 2-3 kmdoğusunda, asfalt yola yaklaşı $200 \mathrm{~m}$ mesafede bulunan bu yazıt, 4-5 m yükseklikteki sarp bir kayanın yüzeyinde bulunmaktadır (Şekil 12 A, B, C). Bu metnin Tuwanuwa (Tuwana) kralı Warpalawas'a (M.Ö. 738-710) bağlı prens Tarhunzas tarafından yazdırıldığ 1 belirtilmiştir (Bossert, 1954). Metinde "Tuwana kralı Urballa" (Hawkins, 1969) olarak sözü edilen kral Warpalawas, "Muti” dağı olarak adlandırılan Bolkardağ yöresini Tarhunzas'a bağışlamaktadır.

İlk Maden Ruhsatı olarak isimlendirilen bu metinde Tarhunzas, kral Warpalawas'1 kastederek 'Efendim Warpalawas'a iyilik ettim, o da Muti dăğ 'nı bana verdi" demektedir. Ayrıca metinde "Kubab" gibi çeşitli tanrı ve tanrıçaların dağ1 bereketli kılması dilenmektedir ki; bu da bereketli olması beklenen madenlerin gümüş madenleri olduğunu düşündürmektedir (Yener, 1938).

Metinde "ve beyim Warpalawa'yu iyi bir şekilde yükselttim (?), o bana süratli (?) katırlar verdi" demektedir. Metnin sonunda "bu yazıtı kim kazırsa (silerse, parçalarsa) bu kimseyi firtına tanrisı ve tanrllar sürsünler (kovsunlar) ve ay tanrisi onu alsin. Ve tanri Nikaruha onu yesin. Tanrl Kupada'da onu ......sin" ifadeleri yer almaktadır (Kalaç, 1976). Metinde geçen süratli (?) katırların madende çıkartılan cevherin taşınmasında kullanıldıklarını söylemek yanlış olmamalidir.

Prof.Dr.K.Aslihan YENER ile yapilan sözlü görüşmede; bu metni okuyan İngiliz bilim adamı Prof.Dr. J.David HAWKINS' in “ Makaleyi yazdıktan sonra yazıt ile ilgili yaptığı çalışmalarda metinde gümüs kelimesini bulduğunu" kendisine ifade ettiğini belirtmiştir.

$\mathrm{Bu}$ da bu yazıtın Bolkarlardaki altıngümüş-kurşun-çinko-bakır ve demir yataklarıyla ilgili verilen ve tarihteki "Illk maden ruhsati" olduğunu göstermektedir. Hititliler ile Misır arasında yapılan ve tarihteki ilk yazılı antlaşma olan Kadeş Antlaşması gibi ilk Maden Ruhsatının yine Anadolu'da verildiğini söylemek yanlış olmamalıdır. Özellikle yerbilimleri açısından son derece önemli olan bu yazıtın koruma altına alınması için girişimlerde bulunulmalıdır. 


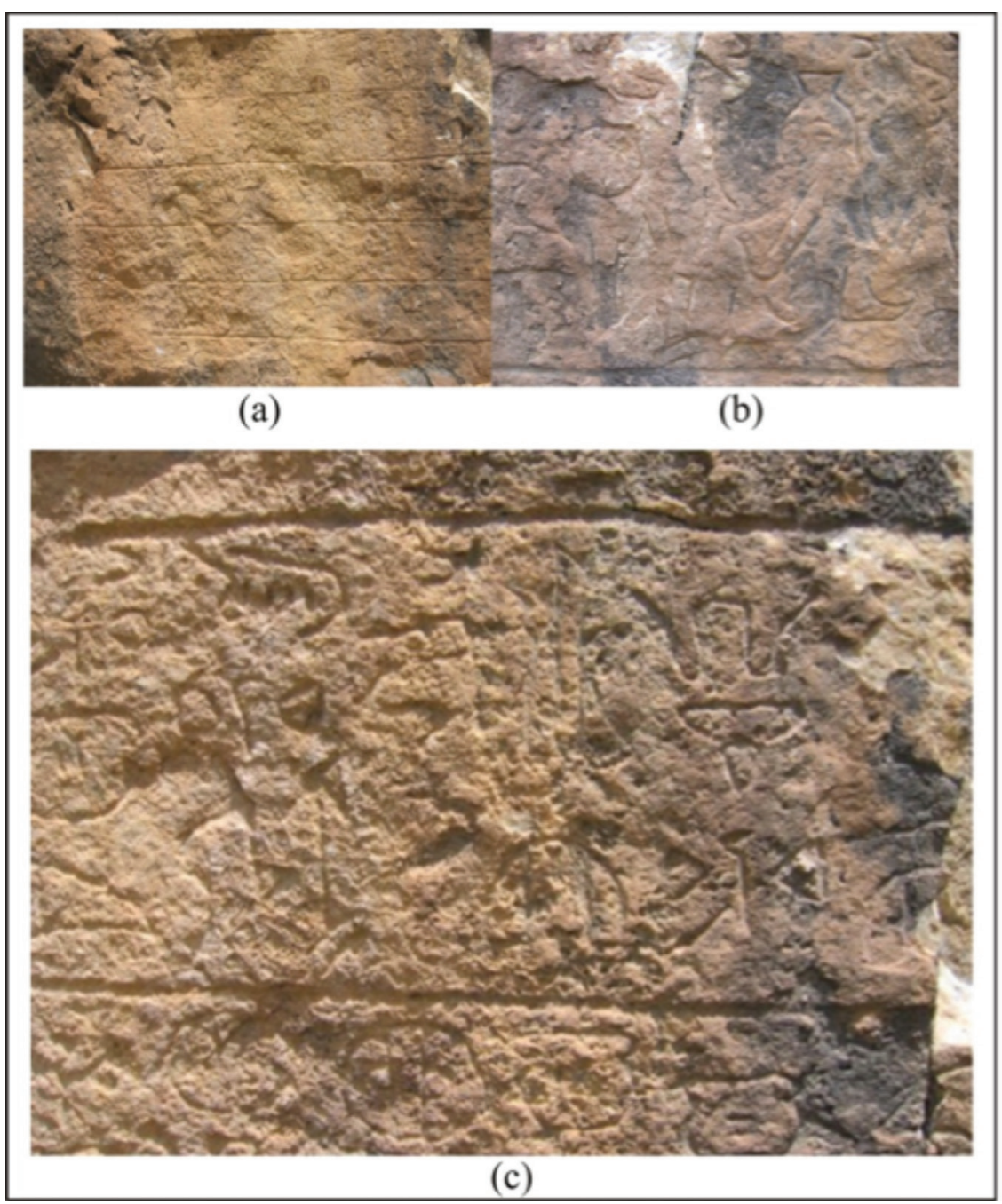

Şekil 12. a) Hiyeroglif yazısı ile yazılmış beş paragraflık "İlk maden ruhsat"nın görünümü, b) İlk maden ruhsatı olan Yazılıtaş’tan ayrıntılı görünüm, c) Yazılıtaş’tan yakın görünüm.

Figure 12. Hieroglyph tablet of the Yazlltass, whole five paragraph of the first "Mining Licence", b) detail view of Yazılıtaş tablet, c) more detail view of Yazllitaş.

\section{SONUÇLAR VE ÖNERILER}

Bu çalışmada, 8 adet eski işletme ve 3 adet cüruf sahası incelenmiştir. $\mathrm{Bu}$ işletmelerden 7 adet kimyasal analiz numunesi, 12 adet $\mathrm{C}^{14}$ numunesi alınmıştır. Madenköy, Madenköy-Karagümüş Mevkii ve Gümüşköy'de bulunan cüruflardan yapılan kimyasal analizlerde $0,8-1,3 \mathrm{~g} / \mathrm{t}$ Au ile 34,7-142,1 g/t Ag varlığı tespit edilmiştir. Bu cüruf yığınları ekonomik açıdan değerlendirilmelidir. Çizelge 6'dan görüldüğü üzere, buradaki eski işletmelerde; Neo-Hitit Döneminden başlayıp Bizans Dönemi'nden Cumhuriyet Dönemi'ne kadar uzanan (zaman zaman ara verilse de) bir üretim söz konusudur. Büyük su teknesi, küçük su teknesi ve madenci ambleminin, tanımlamaları yapılarak MTA Tabiat Tarihi Müzesi envanterine kazandırılmıştır. Yeşelli sahasındaki galeri içinde bulunan sırlı kandil ile eski ve yeni ahşap küreklerin yaş tayinleri yapılarak müze envanterine kazandırılmışlardır. İlk Maden Ruhsatı olan Yazılıtaş koruma altına alınmalıdır. 


\section{KATKI BELIRTME}

Makaleyi inceleyerek, gerekli düzeltme ve düzenlemeler yapan Dr.Yahya Çiftçi ve Dr.Eşref Atabey'e, saha çalışmalarında yardımcı olan Taner Songören'e ve Serkan Kılınçaslan'a, makalenin son şeklini almasındaki önerileri için Hüseyin Yalçın'a teșekkürü borç bilirim.

\section{EXTENDED SUMMARY}

Ancient mines and mining slag's around Ulukışla (Niğde) and Pozantı (Adana) region were investigated in terms of ancient mining point of view. Samples were collected for chemical and radiometric $\left({ }^{14} \mathrm{C}\right)$ analysis from ancient ores and slag's. According to the chemical analysis, Madenköy slags includes $0.8 \mathrm{~g} / \mathrm{t} \mathrm{Au}$ and $142.1 \mathrm{~g} / \mathrm{t}$ Ag; Alihoca-Karagöl slag's includes $1.3 \mathrm{~g} / \mathrm{t} \mathrm{Au}$ and $34.7 \mathrm{~g} / \mathrm{t} \mathrm{Ag}$; Gümüşköy slag's includes $0.9 \mathrm{~g} / \mathrm{t}$ $A u$ and $67.9 \mathrm{~g} / \mathrm{t} \mathrm{Ag}$, and Madenköy-Karagümüş slag's are includes $1.3 \mathrm{~g} / \mathrm{t} \mathrm{Au}$ and $92.8 \mathrm{~g} / \mathrm{t} \mathrm{Ag}$.

$$
\text { Different size vessels, wooden }
$$
fortifications and shovels and firewood's were discovered around Madenköyü, Yeşelli-Büyük Toyislam ancient mines. ${ }^{14} \mathrm{C}$ analysis of big vessel

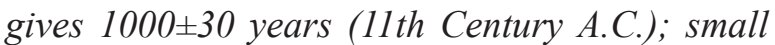
vessel gives $155 \pm 30$ (19th Century A.C.); wooden fortification gives $105 \pm 30$ (19th Century A.C.) radiometric ages. Two wooden shovel discovered around Maden köyü-Büyük Toyislam gives $125 \pm 30$ (20th Century A.C.) and 1000 30 (11th Century A.C.); wooden fortification gives $600 \pm 30$ (15th Century A.C.); firewood gives $385 \pm 30$ (17th Century A.C.) radiometric ages. Firewood of the ancient mine around Horozköy-Gavurun Damı region gives $270 \pm 25$ (18th Century A.C.); ancient wooden fortification gives $205 \pm 25$ (18th-19th Century A.C.) and wooden staircase gives $135 \pm 30$ (19th Century A.C.) radiometric ages.

Wooden charcoals were also analysed according to ${ }^{14} \mathrm{C}$ ages of slag mounds around Karagümüş and Madenköy; $835 \pm 30$ (12th Century A.C.) and $860 \pm 30$ (12th Century A.C.) radiometric ages were observed respectively. According to these radiometric ages, mining works is active starting from Byzantian era to the Republic of Turkey with some interruptions in the region.

Bolkar Mountains is called as "Muti Mountains" in the tablet of Neo-Hatti period in 800 BC, located in eastern part of Alihoca Village. This tablet could be accepted as the "first mining licence" according to its content, thus, mining in the region is active, with some interruptions, since Neo-Hatti Period.

\section{DEĞINIILEN BELGELER}

Ajdukiewicz, Z., 1946. Bolkardağ II. Gümüş-Altın ve Kurşun Yatakları Mıntıkasındaki Maden Aramaları Hakkında Rapor. MTA Genel Müdürlüğü, Rapor No: 1673, Ankara (yayımlanmamış).

Balçık, A., 1974. Niğde Ulukışla-Gümüşköy ve Madenköy curuflarının tenor ve rezerv hesaplamasına yönelik ön çalışma raporudur. MTA Genel Müdürlüğü Maden Etüt ve Arama Dairesi Arşiv No:1789 (yayımlanmamış).

Beral, E., 1865. Bolkardağ Madenleri Hakkında Rapor. MTA Genel Müdürlüğü, Arşiv No: 387, Ankara (yayımlanmamış).

Bossert, H.Th., 1954. Untersuchungen hieroglyphen-hetitischen. Worter 1. Das Wart gut in den Kleinasiatischen Sprachen Mitteilungen des Instituts für Orientforschung Bd II:78103.

Bronk Ramsey, C., 2009. Dealing with outliers and offsets in radiocarbon dating. Radiocarbon, 51(3).

Cokino, M.P., 1927. Bolkardağ Madeni Hakkında Rapor. MTA Genel Müdürlüğü, Arşiv No: 363, Ankara (yayımlanmamış).

Coulant, E., 1884. Bolkardağ Madeni Hakkında Rapor. MTA Genel Müdürlüğü, Arşiv No: 358, Ankara (yayımlanmamış).

Hannebert, H., 1888. Hannebert'in Bolkardağ Madeni Hakkındaki Raporu. MTA Genel Müdürlüğü, Rapor No: 357, Ankara (yayımlanmamış).

Hawkins, J.D., 1969. A Hieroglyphic Hittite Inscption from Porsuk Anatolium Studies, 19, 99-109.

Helke, A., 1929. Bulgar Dağ madeni Hakkında Rapor. MTA Genel Müdürlüğü, Arşiv No: 398, Ankara (yayımlanmamış). 
Hill, A., Stewart, R., 1927. Bolkar Dagh Mines. MTA Genel Müdürlüğü, Arşiv No:1472, Ankara (yayımlanmamış).

Hummel, S., 1938 Bolkardağ Madeni-Triyas Ocağının Cevher Rezervi Hesabı. MTA Genel Müdürlüğü, Rapor No: 418, Ankara (yayımlanmamış)

Kalaç, M., 1976. Bolkar-Maden Kaya Yazıtı. Anadolu Araştırmaları V-VI: 61-69.

Kovenko, V., 1942. Bolkardağ Madenleri Hakkında Not. MTA Genel Müdürlüğü, Rapor No: 313, Ankara (yayımlanmamış).

MTA., 2002. 1/500.000 Ölçekli Türkiye Jeoloji Haritaları Serisi, Adana Paftası. MTA Genel Müdürlüğü Yayını, Ankara.

Müller, M., 1937. Bolkardağ Madeni yatakları Hakkında Rapor. MTA Genel Müdürlüğ̈̈, Derleme Rapor No: 393.

Oelsner, O., 1938. Bolkardağ Madeninde Yapılan Arama İşleri Hakkında Rapor. MTA Genel Müdürlüğü, Derleme Rapor No: 661 .

Ralli, G., 1925. Bolkardağ Maden Ocakları Hakkında Rapor. MTA Genel Müdürlüğü, Arşiv No: 386, Ankara (yayımlanmamış).

Reimer, P. J., Baillie, M. G. L., Bard, E., Bayliss, A., Beck, J. W., Blackwell, P. G., Bronk Ramsey, C., Buck, C. E., Burr, G. S., Edwards, R. L., Friedrich, M., Grootes, P. M., Guilderson, T. P., Hajdas, I., Heaton, T. J., Hogg, A. G., Hughen, K. A., Kaiser, K. F., Kromer, B., McCormac, F. G., Manning, S. W., Reimer, R. W., Richards, D. A., Southon, J. R., Talamo, S., Turney, C. S. M., van der Plicht, J., \& Weyhenmeyer, C. E., 2009. IntCa109 and Marine09 radiocarbon age calibration curves, 0-50,000 years cal BP. Radiocarbon, 51(4), 1111-1150.
Romberg, H., 1937. Bolkardağı'nın Küçük Toyislam kısmının “Cubage”. MTA Genel Müdürlüğü, Rapor No:405

Şişman, N., Şenocak, M. H., Dilek, S., Yazgaç, M., 1981. Bolkardağ Yöresinin Jeolojisi ve Maden Yatakları. MTA Genel Müdürlüğü, Rapor No: 7202, Ankara (yayımlanmamış).

Tylecote, R. F., 1980. Furnaces, crucibles, and slaqs. T.H. Wertime ve J.D. Muhly eds., The Coming of the Age of Iron, pp.183228. New Haven: Yale University Press.

Yener, K. A., 1984. Niğde Ulukışla Bolkardağ kurşun-çinko yatakları ile ilgili çalışmalar. Tübitak Arkeometri ünitesi bilimsel toplantı bildirileri. VI, s. 103-116, Ankara.

Yener, H., 1938. Bolkardağ Madeni Hakkında Fen Raporu. MTA Genel Müdürlüğü Rapor No: 684, Ankara (yayımlanmamış).

Warteman, E., 1888. Sur La Mine De Bulgar Dagh. MTA Genel Müdürlüğü, Derleme Rapor No: 365 Ankara (yayımlanmamış).

$\begin{array}{ll}\text { Makale Geliş Tarihi } & : \text { 5 Şubat } 2014 \\ \text { Kabul Tarihi } & : \text { 31 Mart } 2014 \\ \text { Received } & : \text { 5 February } 2014 \\ \text { Accepted } & : \text { 31 March } 2014\end{array}$

